\title{
A new gas chromatographic method development and validation for the simultaneous determination of ibuprofen and caffeine in bulk and pharmaceutical dosage form
}

\author{
Celine Zambakjian *iD and Amir Alhaj Sakur
}

\begin{abstract}
Background: Ibuprofen is a nonsteroidal anti-inflammatory drug (NSAID) that has analgesic, antiinflammatory, and antipyretic properties. Caffeine is one of the most common adjuvant analgesic drugs which is combined with ibuprofen in commercially available formulations. Combining analgesics offers the possibility of increasing effectiveness without increasing dose and therefore risk. Prescribing ibuprofen and caffeine together is common in clinical practice. This is the first work reporting a new and validated gas chromatographic method for the simultaneous determination of ibuprofen and caffeine in bulk and pharmaceutical dosage form. The separation was performed on a TRB-17 column (30.00 m in length, 0.25$\mathrm{mm} \mathrm{ID}$, and $0.25-\mu \mathrm{m} d f$ ). Detection was carried out using a flame ionization detector (FID). Methyl paraben was used as an internal standard. The injection volume was $1 \mu \mathrm{L}$ with 1:50 split ratio using nitrogen as a carrier gas at a flow rate of $1 \mathrm{~mL} / \mathrm{min}$. The oven temperature was programmed at $150^{\circ} \mathrm{C}$ for $0.5 \mathrm{~min}$, with a rise of $10^{\circ} \mathrm{C} / \mathrm{min}$ up to $250^{\circ} \mathrm{C}$. The injector temperature was $280^{\circ} \mathrm{C}$, and the detector temperature was $300^{\circ} \mathrm{C}$. The validation of the method including linearity, range, detection limit (DL), quantitation limit (QL), accuracy, precision, specificity, system suitability, and robustness was carried out utilizing International Conference on Harmonization (ICH) guidelines.
\end{abstract}

Results: The retention times of methyl paraben, ibuprofen, and caffeine were 1.687, 2.594, and $4.031 \mathrm{~min}$, respectively. The method was linear in the range of $1000-7000 \mu \mathrm{g} / \mathrm{mL}$ for ibuprofen and $162.5-1137.5$ $\mu \mathrm{g} / \mathrm{mL}$ for caffeine with a correlation coefficient of 0.9999 for both drugs. The $\mathrm{DL}$ was found to be $131.68 \mu \mathrm{g} / \mathrm{mL}$ and $15.74 \mu \mathrm{g} / \mathrm{mL}$ for ibuprofen and caffeine, respectively, whereas QL was found to be $399.02 \mu \mathrm{g} / \mathrm{mL}$ for ibuprofen and $47.68 \mu \mathrm{g} / \mathrm{mL}$ for caffeine. The accuracy of the method was validated by mean percentage recovery, which was found to be in the acceptable range. The precision study results of the new method were less than the maximum allowable limit percentage of relative standard deviation \%RSD $\leq 2.0$.

The specificity was evaluated by the standard edition method, and the results of the recovery data (Continued on next page)

\footnotetext{
* Correspondence: celinezam94@gmail.com

Department of Food \& Analytical Chemistry, Faculty of Pharmacy, University of Aleppo, Aleppo, Syria
}

\section{Springer Open}

(ㅇ The Author(s). 2020 Open Access This article is licensed under a Creative Commons Attribution 4.0 International License, which permits use, sharing, adaptation, distribution and reproduction in any medium or format, as long as you give appropriate credit to the original author(s) and the source, provide a link to the Creative Commons licence, and indicate if changes were made. The images or other third party material in this article are included in the article's Creative Commons licence, unless indicated otherwise in a credit line to the material. If material is not included in the article's Creative Commons licence and your intended use is not permitted by statutory regulation or exceeds the permitted use, you will need to obtain permission directly from the copyright holder. To view a copy of this licence, visit http://creativecommons.org/licenses/by/4.0/. 
(Continued from previous page)

showed that excipients do not affect the accuracy of the proposed method. The results of system

suitability and robustness tests were also within the acceptable limits.

Conclusion: The first reported method for simultaneous determination of ibuprofen and caffeine by gas chromatography in bulk and combined dosage form was carried out in this work. The developed method gave a good separation of the drugs and internal standard. The analytical performance of the method was statistically validated as per $\mathrm{ICH}$ guidelines, and satisfactory results were obtained. The proposed method can be easily adopted for the routine analysis of ibuprofen and caffeine.

Keywords: Gas chromatography, Ibuprofen, Caffeine, Simultaneous determination

\section{Background}

Ibuprofen (IBU) is a nonsteroidal anti-inflammatory drug (NSAID) that has analgesic, anti-inflammatory, and antipyretic properties [1]. Caffeine (CAF) is one of the most common adjuvant analgesic drugs, also found in many beverages such as coffee and cola drinks [1]. The chemical structures of these drugs are given in Fig. 1.

There are compendial methods for the singly assessment of these two drugs in United States Pharmacopeia (USP) [2] and British Pharmacopeia (BP) [3].

IBU alone or in combination with other drugs was determined using a variety of analytical techniques including gas chromatography (GC) [4, 5], highperformance liquid chromatography (HPLC) [5-7], spectrophotometry [8,9], kinetic spectrophotometry [10], spectrofluorometry [11], colorimetry [12], and infrared (IR) spectroscopy [13].

The review of literature revealed that CAF alone or with its pharmaceutical combinations has been estimated by GC [14-16], HPLC [17-20], and spectrophotometric techniques [21-23].

The determination of the combination of IBU and CAF has been reported using spectrophotometry [24] and spectrofluorometry [25]. No attempts have yet been made to determine this drug combination by GC.

In the present work, a new gas chromatographic method is proposed and validated for the simultaneous determination of IBU and CAF in their bulk and pharmaceutical dosage form.

\section{Methods}

\section{Apparatus}

All measurements were performed using Varian 3800 GC system which is equipped with a flame ionization detector (FID), and the data was recorded using the Star Chromatography Workstation version 6.41 software.

\section{Chromatographic conditions}

The separation was performed on a TRB-17 column (30 $\mathrm{m}$ in length, $0.25-\mathrm{mm}$ ID, and $0.25-\mu \mathrm{m} \mathrm{df}$ ) manufactured by Teknokroma. Detection was carried out using FID. Methyl paraben was used as an internal standard (IS). The optimized conditions were injection volume $1 \mu \mathrm{L}$ in split mode 1:50, the carrier gas nitrogen at a constant flow of $1 \mathrm{~mL} / \mathrm{min}$, the injector temperature $280^{\circ} \mathrm{C}$, and the detector $300^{\circ} \mathrm{C}$, and the initial oven temperature $150{ }^{\circ} \mathrm{C}$ was held for $0.5 \mathrm{~min}$, then programmed to increase at a $10^{\circ} \mathrm{C} / \mathrm{min}$ rate up to $250{ }^{\circ} \mathrm{C}$.

\section{Preparation of standard stock solution}

The standard stock solution was prepared by dissolving accurately weighed $500.00 \mathrm{mg}$ IBU and $81.25 \mathrm{mg}$ CAF in chloroform in a $50-\mathrm{mL}$ volumetric flask to get a stock solution containing $10 \mathrm{mg} / \mathrm{mL}$ IBU and $1.625 \mathrm{mg} / \mathrm{mL}$ CAF.

\section{Preparation of internal standard solution}

A solution of $1 \mathrm{mg} / \mathrm{mL}$ methyl paraben was prepared in chloroform. One milliliter of IS was added to flasks for validation tests.

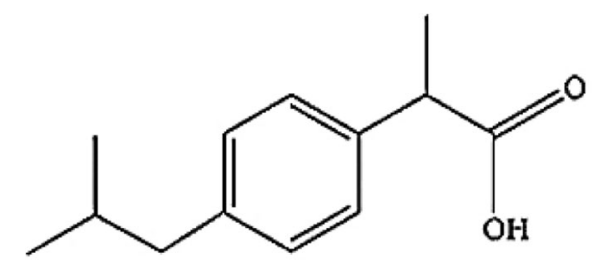

A<smiles>Cn1c(=O)c2c(ncn2C)n(C)c1=O</smiles>

B

Fig. 1 Chemical structures of IBU (a) and CAF (b) 


\section{Sample preparation for tablets}

Twenty tablets of marketed formulation (Profinal, Julphar Life) were accurately powdered. A quantity of powder equivalent to $500.0 \mathrm{mg}$ of IBU and 81.5 $\mathrm{mg}$ of CAF was transferred to a $25-\mathrm{mL}$ volumetric flask, about $10 \mathrm{~mL}$ chloroform was added and sonicated for 5 min to dissolve properly, then the volume was made up to the mark with the same diluent. The sample solution was then filtered through Whatman filter paper No.41. From the filtrate, $2 \mathrm{~mL}$ was taken and transferred to a 10$\mathrm{mL}$ volumetric flask, and $1 \mathrm{~mL}$ of IS was added. The volume was made up to the mark with chloroform to get a solution containing $4.00 \mathrm{mg} / \mathrm{mL}$ of IBU and $0.65 \mathrm{mg} / \mathrm{mL}$ of CAF.

\section{Method validation}

The results of the analysis were validated statistically and carried out as per International Conference on Harmonization (ICH) guidelines Q2 (R1) [26] including linearity, range, detection limit (DL), quantitation limit (QL), accuracy, precision, specificity, system suitability, and robustness.

\section{System suitability}

The system suitability test was assessed by five replicate injections of the system suitability test solution which contains $4000 \mu \mathrm{g} / \mathrm{mL}$ IBU, $650 \mu \mathrm{g} / \mathrm{mL}$ CAF, and $1000 \mu \mathrm{g} / \mathrm{mL}$ IS. The following parameters are determined: \%RSD of retention time values and peak area ratios (drug/IS), theoretical plates, tailing factor, and resolution.

\section{Linearity and range}

The standard solutions were prepared by diluting the stock solution with chloroform to reach concentration ranges $1000-7000 \mu \mathrm{g} / \mathrm{mL}$ and $162.5-1137.5 \mu \mathrm{g} / \mathrm{mL}$ for IBU and CAF, respectively. Nine different concentrations of each compound were chosen with triplicate injections for each concentration and chromatographed under the previously described GC conditions. The linearity of the proposed method was evaluated by using calibration curves to obtain the regression equations and calculate correlation coefficients.

\section{Detection Limit (DL) and Quantitation Limit (QL)}

Several strategies for the determination of DL and QL have been described in the ICH guideline. In this research, the DL and QL values of the proposed method were calculated according to Eqs. 1 and 2:

$$
\mathrm{DL}=3.3 \frac{\sigma}{\mathrm{S}}
$$

$$
\mathrm{QL}=10 \frac{\sigma}{\mathrm{S}}
$$

where:

$\sigma=$ the standard deviation of $y$-intercepts.

$S=$ the slope of the calibration curves.

\section{Accuracy and precision}

The accuracy of the method was examined at three concentration levels for both IBU (3200, 4000, $4800 \mu \mathrm{g} / \mathrm{mL}$ ) and $\operatorname{CAF}(520,650,780 \mu \mathrm{g} / \mathrm{mL})$ with five replicate determinations for each concentration.

The precision of the method was demonstrated by intra-day and inter-day variation studies.

In the intra-day study, five replicate analyses of the three concentration levels mentioned above for IBU and CAF were made and the mean percentage RSD was calculated for each concentration. In the inter-day variation study, five replicate analyses of the three concentrations were made for five consecutive days and the mean percentage RSD was calculated for each concentration.

\section{Specificity}

The specificity was evaluated by the standard edition method. The proposed method was applied to the solution of the tablet formulation to which known quantities of each drug substance had been added and the percentage of analytes recovered by the assay was calculated to ensure that excipients in the tablet formulation do not affect the accuracy of the proposed method.

\section{Robustness}

The robustness of the method was evaluated by analyzing the system suitability standard and evaluating system suitability parameters, \%RSD of retention time and peak area (drug/IS) after varying the initial temperature of the oven $\left( \pm 2.0^{\circ} \mathrm{C}\right)$ and the flow rate $( \pm 0.1 \mathrm{~mL})$.

\section{Results}

\section{Chromatography}

The TRB-17 column gave a good separation of the drugs and IS. The retention times of IBU and CAF were 2.594 and $4.031 \mathrm{~min}$, respectively. The retention time of the IS is $1.687 \mathrm{~min}$ as shown in Fig. 2.

\section{Method validation}

System suitability

Five replicate injections of the system suitability test solution were made. All system suitability parameters including the number of theoretical plates, tailing factor, and resolution were met the acceptance limits. Also, the $\%$ RSD of retention time values $\left(t_{\mathrm{R}}\right)$ and peak area ratios (drug/IS) of five injections does not exceed 2\%, which means that the system is precise (injection repeatability) 


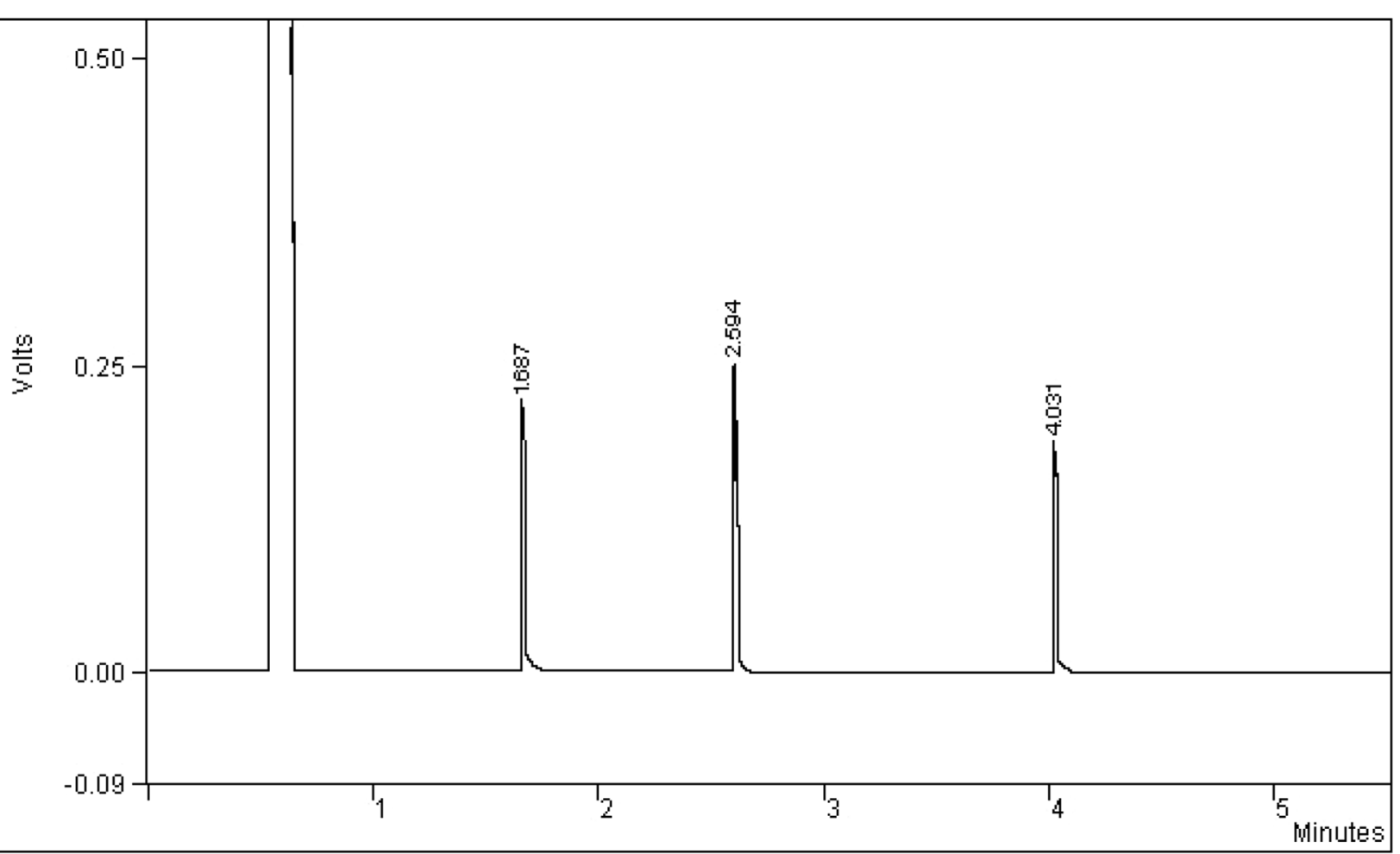

Fig. 2 Chromatogram of a standard solution of IS (1.687min), IBU (2.594min) and CAF (4.031 min), all at 1mg/mL

and suitable for the analysis of IBU and CAF combination. The results are summarized in Table 1.

\section{Linearity and range}

Under the previously described GC conditions, the calibration curves of IBU and CAF were constructed by plotting the peak area ratios (drug/IS) against the concentration of drugs. The results show that an excellent correlation exists between the response factor and the concentration of drugs. The concentration ranges, slope, intercept, and correlation coefficients are listed in Table 2.

\section{Detection Limit (DL) and Quantitation Limit (QL)}

The DL was found to be $131.68 \mu \mathrm{g} / \mathrm{mL}$ and $15.74 \mu \mathrm{g} / \mathrm{mL}$ for IBU and CAF, respectively, whereas QL was found to be $399.02 \mu \mathrm{g} / \mathrm{mL}$ for IBU and $47.68 \mu \mathrm{g} / \mathrm{mL}$ for CAF.

Table 1 System suitability parameters

\begin{tabular}{lll}
\hline Parameter & IBU $^{\mathbf{a}}$ & CAF $^{\mathbf{a}}$ \\
\hline \%RSD of $t_{\mathrm{R}}$ & 0.05 & 0.04 \\
\%RSD of area (drug/IS) & 0.54 & 0.45 \\
Number of theoretical plates & 129940 & 125500 \\
Tailing factor $_{\text {Resolution }}{ }^{\mathrm{b}}$ & 1.02 & 1.10 \\
\hline
\end{tabular}

${ }^{a_{\% R S D}}$ of five injections and the system suitability parameters are mean of five injections

${ }^{\mathrm{b}}$ Resolution with respect to former peak

\section{Accuracy and precision}

The accuracy and precision of the method were examined at three concentration levels 3200, 4000, and 4800 $\mu \mathrm{g} / \mathrm{mL}$ for IBU and $520,650,780 \mu \mathrm{g} / \mathrm{mL}$ for CAF by five replicate determinations for each concentration.

The mean recovery values are found to be $100.51 \%$ and $99.49 \%$ as shown in Table 2 intra-day. The percentage of accuracy for the two drugs was found within the acceptance limit, which means that the method is accurate.

The \%RSD values found in the precision study showed that the proposed method provides acceptable intra-day and inter-day variations for IBU and CAF in their simultaneous determination, which means that the method is precise. The results are summarized in Table 3 where $\%$ RSD was within the limit $\leq 2$.

The accuracy of the method in tablet formulation was evaluated by standard addition method as shown in the "specificity" paragraph.

Table 2 Linear regression data for calibration curves

\begin{tabular}{lll}
\hline & Ibuprofen & Caffeine \\
\hline Concentration range $(\mu \mathrm{g} / \mathrm{mL})$ & $1000-7000$ & $162.5-1137.5$ \\
Slope & 0.0124 & 0.0054 \\
Intercept & 1.0093 & 0.1282 \\
Correlation coefficient & 0.9999 & 0.9999 \\
\hline
\end{tabular}


Table 3 Accuracy and precision for the determination of IBU and CAF

\begin{tabular}{|c|c|c|c|c|}
\hline Analyte & Nominal value $(\mu \mathrm{g} / \mathrm{mL})$ & Found value $^{\mathrm{a}}(\mu \mathrm{g} / \mathrm{mL})$ & \%Recovery & \%RSD \\
\hline \multicolumn{5}{|l|}{ Intra-day } \\
\hline \multirow[t]{3}{*}{$\mathrm{IBU}$} & 3200 & 3237.80 & 101.18 & 0.49 \\
\hline & 4000 & 4004.32 & 100.11 & 0.70 \\
\hline & 4800 & 4812.23 & 100.25 & 0.93 \\
\hline \multirow[t]{3}{*}{ CAF } & 520 & 518.72 & 99.75 & 1.14 \\
\hline & 650 & 645.94 & 99.37 & 0.90 \\
\hline & 780 & 774.88 & 99.34 & 0.49 \\
\hline \multicolumn{5}{|l|}{ Inter-day } \\
\hline \multirow[t]{3}{*}{$\mathrm{IBU}$} & 3200 & 3233.76 & 101.05 & 1.75 \\
\hline & 4000 & 4016.49 & 100.41 & 1.69 \\
\hline & 4800 & 4718.18 & 98.30 & 1.10 \\
\hline \multirow[t]{3}{*}{ CAF } & 520 & 511.66 & 98.40 & 1.75 \\
\hline & 650 & 649.17 & 99.87 & 1.36 \\
\hline & 780 & 779.52 & 99.94 & 1.55 \\
\hline
\end{tabular}

${ }^{\mathrm{a}}$ Mean of five determinations

\section{Specificity}

The specificity was studied by applying the proposed method to the solution of the tablet formulation to which known quantities of each drug substance had been added [3200, 4000, and $4800 \mu \mathrm{g} / \mathrm{mL}$ for IBU and 520, 650, and $780 \mu \mathrm{g} / \mathrm{mL}$ for CAF] with five replicate determinations for each concentration. The specificity was expressed as the percentage of analytes recovered by the assay to ensure that excipients in the tablet formulation do not affect the accuracy of the proposed method. The recoveries for IBU and CAF from the specific formulation are shown in Table 4. The results indicated the specificity of the method for the simultaneous determination of both drugs as revealed by recovery data.

\section{Robustness}

The robustness of the method was studied by analyzing the system suitability standard after deliberately changing the initial temperature of the oven $\left( \pm 2.0^{\circ} \mathrm{C}\right)$ and the flow rate $( \pm 0.1 \mathrm{~mL})$. These variations did not have significant effects on retention times and peak areas; also, the system suitability parameters remain within acceptable limits as shown in Table 5.

\section{Analysis of tablet formulation}

The developed chromatographic method was applied for the assay of the two drugs in their combined tablet formulation (400 mg IBU, $65 \mathrm{mg}$ CAF). The analysis procedure was repeated five times with tablet formulation. Table 6 shows the results obtained from the proposed method as well as the reference HPLC method [18]. The assay results showed good accuracy and precision, and no interfering peaks were observed in the chromatograms of the tablets. Results obtained by the developed method were statistically compared with those of the previously published HPLC chromatographic method using Student's $t$ test for accuracy and $F$ test for precision, which are considered useful statistical tools for comparison of results obtained from two methods. The calculated $t$ and $F$ values did not exceed the critical values for either of the two drugs, indicating no significant differences between the proposed method and the reference method.

\section{Discussion}

This research involved a new gas chromatographic method for the simultaneous determination of IBU and

Table 4 Specificity for the determination of IBU and CAF by the standard edition method

\begin{tabular}{|c|c|c|c|c|c|}
\hline Analyte & Sample concentration $(\mu \mathrm{g} / \mathrm{mL})$ & Added concentration $(\mu \mathrm{g} / \mathrm{mL})$ & Nominal value $(\mu \mathrm{g} / \mathrm{mL})$ & Found value $^{\mathrm{a}}(\mu \mathrm{g} / \mathrm{mL})$ & \%Recovery \\
\hline \multirow[t]{3}{*}{$\mathrm{IBU}$} & 4000 & 3200 & 7200 & 7199.30 & 99.99 \\
\hline & & 4000 & 8000 & 8001.65 & 100.02 \\
\hline & & 4800 & 8800 & 8798.75 & 99.98 \\
\hline \multirow[t]{3}{*}{ CAF } & 650 & 520 & 1170 & 1169.00 & 99.91 \\
\hline & & 650 & 1300 & 1295.99 & 99.69 \\
\hline & & 780 & 1430 & 1428.64 & 99.90 \\
\hline
\end{tabular}


Table 5 Robustness of the method

\begin{tabular}{|c|c|c|c|c|c|c|c|c|c|c|c|}
\hline \multicolumn{2}{|l|}{ Parameter changes } & \multicolumn{2}{|c|}{ Retention time } & \multicolumn{2}{|c|}{ Area ratio } & \multicolumn{2}{|c|}{ Theoretical plates } & \multicolumn{2}{|c|}{ Tailing factor } & \multicolumn{2}{|c|}{ Resolution $^{\mathrm{a}}$} \\
\hline & & IBU & CAF & IBU/IS & $\overline{C A F / I S}$ & IBU & CAF & IBU & CAF & IBU & CAF \\
\hline \multirow[t]{3}{*}{ Initial temperature of the oven } & $148^{\circ} \mathrm{C}$ & 2.61 & 4.10 & 50.70 & 3.65 & 128475 & 125034 & 1.04 & 1.12 & 19.77 & 25.00 \\
\hline & $150^{\circ} \mathrm{C}$ & 2.59 & 4.03 & 50.66 & 3.62 & 129940 & 125500 & 1.02 & 1.10 & 19.99 & 25.01 \\
\hline & $152^{\circ} \mathrm{C}$ & 2.53 & 4.00 & 50.59 & 3.60 & 130100 & 126500 & 1.01 & 1.09 & 20.00 & 25.55 \\
\hline$\%$ RSD & & 1.66 & 1.25 & 0.11 & 0.70 & - & & - & & - & \\
\hline \multirow[t]{3}{*}{ Flow rate } & $0.9 \mathrm{~mL} / \mathrm{min}$ & 2.61 & 4.09 & 50.9 & 3.65 & 128888 & 122847 & 1.03 & 1.12 & 20.00 & 24.99 \\
\hline & $1 \mathrm{~mL} / \mathrm{min}$ & 2.59 & 4.02 & 50.60 & 3.61 & 129925 & 125499 & 1.01 & 1.10 & 20.01 & 25.19 \\
\hline & $1.1 \mathrm{~mL} / \mathrm{min}$ & 2.52 & 4.01 & 50.50 & 3.58 & 130487 & 127374 & 1.00 & 1.09 & 20.09 & 25.25 \\
\hline$\%$ RSD & & 1.84 & 1.08 & 0.41 & 0.97 & - & & - & & - & \\
\hline
\end{tabular}

${ }^{\mathrm{a}}$ Resolution with respect to former peak

CAF in bulk and pharmaceutical dosage form using the TRB-17 column and methyl paraben as an internal standard. Previous studies have shown the determination of IBU and CAF individually by GC in different matrices $[4,5,14-16]$. However, the simultaneous determination of these two analytes in pharmaceutical binary mixture using GC has not been previously reported.

The described validated chromatographic method offers selectivity advantage over the spectrophotometricbased non-separation methods. Also, there are some drawbacks in HPLC methods such as the use of large amounts of organic solvents, which is not cost-effective for routine analysis in pharmaceutical industries.

The primary goal of this study is to provide a direct, requiring minimal sample preparation, fast, and reliable method for such determination. The simplicity and costeffectiveness of the proposed method support the objective of the research work as this method needs no derivatization or pretreatment of the target compounds.

During the development of the analytical method in this research, several temperature programs were evaluated. Programs with higher initial temperatures or higher ramp rates led to poor resolution, whereas lower temperature ramps resulted in longer retention times and excessive peak tailing, and a program showing the best resolution in a reasonable analysis time was selected. IBU eluted first $\left(t_{\mathrm{R}}=2.594 \mathrm{~min}\right)$ followed by CAF $\left(t_{\mathrm{R}}=4.031 \mathrm{~min}\right)$, and the resolution $\left(R_{\mathrm{s}}\right)$ was found to be
25.01. Methyl paraben was chosen as an internal standard because its peak $\left(t_{\mathrm{R}}=1.687 \mathrm{~min}\right)$ was completely separated from the other peaks.

The system suitability parameters like injection repeatability, peak resolution, tailing factor, and the number of theoretical plates were met the acceptance limits (Table 1), which means that the equipment, electronics, analytical operations, and samples to be analyzed constitute an integral system that can be used for the determination of the drug combination.

The validation of the developed analytical method was completed with respect to linearity, range, DL, QL, accuracy, precision, specificity, and robustness.

The different concentrations of standard solutions of IBU and CAF gave linearity between the ranges of $1000-7000 \mu \mathrm{g} / \mathrm{mL}$ for IBU and $162.5-1137.5 \mu \mathrm{g} / \mathrm{mL}$ for CAF with a correlation coefficient of 0.9999 for both drugs.

The DL for IBU and CAF was found to be $131.68 \mu \mathrm{g} /$ $\mathrm{mL}$ and $15.74 \mu \mathrm{g} / \mathrm{mL}$, respectively. The QL for IBU and CAF was found to be $399.02 \mu \mathrm{g} / \mathrm{mL}$ and $47.68 \mu \mathrm{g} / \mathrm{mL}$, respectively. These are good values taking into account the split ratio 1:50.

For the accuracy and precision studies, three concentration levels were chosen for IBU $(3200,4000,4800 \mu \mathrm{g} /$ $\mathrm{mL})$ and CAF $(520,650,780 \mu \mathrm{g} / \mathrm{mL})$ and five replicate determinations were done for each concentration. The intra-day and inter-day estimation was carried out for

Table 6 Application of the proposed method in the analysis of IBU and CAF commercial tablet

\begin{tabular}{|c|c|c|c|c|c|}
\hline Analyte & Method & \%Recovery ${ }^{a}$ & SD & $F$ value $^{\mathrm{b}}$ & $t$ value $^{c}$ \\
\hline \multirow[t]{2}{*}{$\mathrm{IBU}$} & GC & 100.44 & 0.95 & 3.93 & 2.09 \\
\hline & HPLC (reference method) & 99.70 & 0.48 & & \\
\hline \multirow[t]{2}{*}{ CAF } & GC & 100.97 & 0.79 & 1.74 & 1.14 \\
\hline & HPLC (reference method) & 100.61 & 0.60 & & \\
\hline
\end{tabular}

\footnotetext{
${ }^{a}$ Mean of five determinations

${ }^{\mathrm{b}}$ The critical value for $F$ equals 6.388 at $p=0.05$

'The critical value for $t$ equals 2.776 at $p=0.05$
} 
the three selected concentrations of IBU and CAF. The percentage of accuracy for the two drugs was found within the acceptance limit, and the \%RSD values in intra-day and inter-day precision studies were less than the maximum allowable limit percentage of $\% \mathrm{RSD} \leq 2$.

The specificity was evaluated by the standard edition method; as known quantities of each drug substance had been added to the solution of the tablet formulation, the results of the recovery data showed that excipients do not affect the accuracy of the proposed method.

The robustness of the developed method was determined by deliberately changing in method parameters, such as the initial temperature of the oven $\left( \pm 2.0^{\circ} \mathrm{C}\right)$ and the flow rate $( \pm 0.1 \mathrm{ml})$. These variations did not have a significant effect on the measured responses (Table 5).

Finally, the proposed method was found to be convenient for the routine analysis of IBU and CAF.

\section{Conclusion}

In the present work, we developed an accurate, precise, linear, robust, and simple gas chromatographic method for the simultaneous determination of IBU and CAF in bulk and pharmaceutical dosage form. The proposed method gave a good resolution between the drugs with short analysis time (about $4 \mathrm{~min}$ ). The analytical performance of the method was statistically validated as per $\mathrm{ICH}$ guidelines, and satisfactory results were obtained. In addition, to the best of our knowledge, this is the first time that simultaneous determination of IBU and CAF using GC is reported.

\section{Abbreviations}

BP: British Pharmacopeia; CAF: Caffeine; df: Film thickness; DL: Detection limit; FID: Flame ionization detector; GC: Gas chromatography; HPLC: Highperformance liquid chromatography; IBU: Ibuprofen; ICH: International Conference on Harmonization; ID: Internal diameter; IR: Infrared; IS: Internal standard; NSAID: Nonsteroidal anti-inflammatory drug; QL: Quantitation limit; RSD: Relative standard deviation; USP: United States Pharmacopeia

\section{Acknowledgements}

The authors are grateful to the Department of Food \& Analytical Chemistry, Faculty of Pharmacy, University of Aleppo, for providing all the facilities necessary to complete this research.

\section{Authors' contributions}

CZ carried out all experiments in the research, including the development of the method (choosing the appropriate chromatographic conditions that show the best resolution in a reasonable analysis time for the determination of ibuprofen and caffeine using methyl paraben as an internal standard) and then the validation of the developed method including linearity, range, detection limit $(\mathrm{DL})$, quantitation limit $(\mathrm{QL})$, accuracy, precision, system suitability, and robustness. CZ also wrote the manuscript. AAS supervised the research in all stages, contributed to the analysis of the data to obtain an ideal analytical method for the determination of ibuprofen and caffeine by gas chromatography, and revised the manuscript. All authors have read and approved the manuscript.

\section{Funding}

Not applicable.
Ethics approval and consent to participate

Not applicable.

\section{Consent for publication}

Not applicable.

\section{Competing interests}

The authors declare that they have no competing interests.

Received: 22 July 2020 Accepted: 4 October 2020

Published online: 03 December 2020

\section{References}

1. Sweetman SC (2009) Martindale: The complete drug reference, 36th edn. Pharmaceutical Press, United Kingdom

2. United States Pharmacopeia: USP 30 - The National Formulary: NF 25, 2007.

3. The British pharmacopoeia. (2009) Vol. I \& II. London: Medicinal Substances.

4. Cretu G, lonică M, Dănet AF, Enein HA, Macovei R, Buleandră M (2005) Separation of the enantiomers of Ibuprofen by a gas chromatographicmass spectrometric method. Acta Chromatogr 15:315-321

5. Caviglioli G, Valeria P, Brunella P, Sergio C, Attilia A, Gaetano B (2002) Identification of degradation products of ibuprofen arising from oxidative and thermal treatments. J Pharm Biomed Anal 30:499-509

6. Pattanaik S, Mukhi S, Pattnaik G, Panda J (2013) Assay method development and validation of ibuprofen tablets by HPLC. Der Pharmacia Sinica 4(4):91-96

7. Radi M, Ramli Y, El Karbane M, Elalami A, Karrouchi K, Bekkali A, Benaji B, Issmaili S, Bakhous K (2014) Optimization and validation of a method for determination of Ibuprofen by HPLC in different pharmaceutical forms: tablet, syrup, gel and suppository. J Chem Pharm Res 6(8):301-304

8. Sunaric S, Petkovic M, Denic M, Mitic S, Pavlovic A (2013) Determination of ibuprofen in combined dosage forms and cream by direct UV spectrophotometry after solid-phase extraction. Acta Pol Pharm Drug Res 70(3):403-411

9. Zayed MA, EL-Gizouli AMM (2017) Spectrophotometric study and determination of ibuprofen and lornoxicam drugs via their reaction with copper (II) reagent and their biological activities. J Pharm Appl Chem 3(1): $75-82$

10. Mitić SS, Miletić Miletić GŽ, Pavlović AN, Arsić BB, Živanović W (2008) Quantitative analysis of ibuprofen in pharmaceuticals and human control serum using kinetic spectrophotometry. J Serbian Chem Soc 73(8-9):879-890

11. Damiani PC, Bearzotti M, Cabezón MA (2001) Spectrofluorometric determination of ibuprofen in pharmaceutical formulations. J Pharm Biomed Anal 25:679-683

12. Bahram M, Madrakian T, Sakineh Alizadeh S (2017) Simultaneous colorimetric determination of morphine and ibuprofen based on the aggregation of gold nanoparticles using partial least square. J Pharm Anal 7: $411-416$

13. Matkovic SR, Valle GM, Briand LE (2005) Quantitative analysis of ibuprofen in pharmaceutical formulations through FTIR spectroscopy. Lat Am Appl Res 35:189-195

14. Pasias IN, Kiriakou I, Proestos C (2017) Development of a rapid method for the determination of caffeine in coffee grains by GC-FID: a fully validated approach. Antioxidants 6(3):67

15. Lisko JG, Lee GE, Kimbrell JB, Rybak ME, Blasini LV, Watson CH (2017) Caffeine concentrations in coffee, tea, chocolate, and energy drink flavored E-liquids. Nicotine Tob Res 19(4):484-492

16. Edwards QA, Hinkson SAS, O'neale LDG, Kulikov SM (2015) Quantification of caffeine in selected beverages via gas chromatography-mass spectroscopy. Int J Chem Sci 13(1):133-142

17. Fajara BEP, Susanti H (2017) HPLC determination of caffeine in coffee beverage. IOP Conf Series Mater Sci Eng 259

18. Palled PJ, Dushyanth RV, Mannor VS, Chowdary B (2017) Validated isocratic/ gradient RP-HPLC for simultaneous estimation of paracetamol, ibuprofen and caffeine in marketed formulations using diclofenac as internal standard. Anal Chem Ind J 17(1):116

19. Lopez-Sanchez RC, Lara-Diaz VJ, Aranda-Gutierrez A, Martinez-Cardona JA Hernandez JA (2018) HPLC method for quantification of caffeine and its three major metabolites in human plasma using fetal bovine serum matrix to evaluate prenatal drug exposure. J Anal Methods Chem 2018:1-11

20. Cunha RR, Chaves SC, Ribeiro MMAC, Torres LMFC, Muñoz RAA, Dos Santos WTP, Richter EM (2015) Simultaneous determination of caffeine, 
paracetamol, and ibuprofen in pharmaceutical formulations by highperformance liquid chromatography with UV detection and by capillary electrophoresis with conductivity detection. J Sep Sci 38:1657-1662

21. Alkhafaji SL, Mahood AM (2018) First-order derivative and UVspectrophotometric methods for simultaneous determination of paracetamol, ibuprofen, and caffeine in bulk and pharmaceutical formulation. J Pharm Res Int 25(2):1-14

22. Bhawani SA, Fong SS, Ibrahim MNM (2015) Spectrophotometric analysis of caffeine. Int J Anal Chem 2015:1-7.

23. Aktaş AH, Kitiş F (2014) Spectrophotometric simultaneous determination of caffeine and paracetamol in commercial pharmaceutical by principal component regression, partial least squares and artificial neural networks chemometric methods. Croat Chem Acta 87(1):69-74

24. Saeed AM, Ahmed NQ (2018) Development spectrophotometric method for simultaneous estimation of ibuprofen and caffeine in pure and tablet dosage forms. Eur J Biomed Pharm Sci 5(4):1059-1063

25. Mohammadnejad M (2016) Simultaneous determination of ibuprofen and caffeine in urine samples by combining MCR-ALS and excitation-emission data. Anal Bioanal Chem Res 3(1):123-130

26. International Conference on Harmonization (ICH) Harmonized Tripartite Guideline: Validation of analytical procedures: text and methodology Q2(R1), 2005.

\section{Publisher's Note}

Springer Nature remains neutral with regard to jurisdictional claims in published maps and institutional affiliations.

\section{Submit your manuscript to a SpringerOpen ${ }^{\circ}$ journal and benefit from:}

- Convenient online submission

- Rigorous peer review

- Open access: articles freely available online

- High visibility within the field

- Retaining the copyright to your article 